\title{
Transmission of extramembrane conformational change into current; construction of metal-gated ion channel
}

Tatsuto Kiwada, Kazuhiro Sonomura, Yukio Sugiura, Koji Asami, and Shiroh Futaki ${ }^{\star}$

Institute for Chemical Research, Kyoto University, Uji, Kyoto 611-0011, Japan

E-mail: futaki@scl.kyoto-u.ac.jp

\section{Supporting Information}

\section{Preparation of Alm-[Ida]Fos and [Ida]Fos peptides}

Peptide synthesis was conducted by Fmoc-solid-phase synthesis on Rink amide resin similarly as reported (Figure S1). ${ }^{8,12}$ A protected peptide corresponding to the positions $18-64$ of Alm-[Ida]Fos was prepared by a Shimadzu PSSM-8 synthesizer using a benzotriazole-1yl-oxy-tris-pyrrolidino-phosphonium hexafluorophosphate (PyBOP)/1-hydroxybenzotriazole (HOBt)/4-methylmorpholine (NMM) coupling system. Here the 4-methyltrityl derivative of lysine $[\mathrm{Lys}(\mathrm{Mtt})]^{\mathrm{S} 1}$ was employed for Lys that is converted to Ida (positions 42 and 44), and Fmoc-Lys(Boc) for Lys that is not converted. Because of the steric hindrance of Aib residing in the alamethicin segment, the peptide chain corresponding to the positions 1-17 was then elongated manually using the Fmoc-amino-acid fluoride method. ${ }^{\mathrm{S2}}$ The N-terminal of the peptide resin was acetylated using acetic anhydride in the presence of NMM. After construction of the protected peptide resin, the Mtt group was removed from the peptide resin by the treatment of 1,1,1,3,3,3-hexafluoro-2-propanol (HFIP) in dichloromethane (DCM) 
(1:4) at $20^{\circ} \mathrm{C}$ for $24 \mathrm{~h}$, where other protecting groups and peptide anchoring on the resin remain intact. Subsequent treatment of the peptide resin with tetra-n-butylammonium iodide $\left(\mathrm{nBu}_{4} \mathrm{NI}\right)(20 \mathrm{eq})$, bromoacetic acid tert-butyl ester $(50 \mathrm{eq})$ and diisopropylethylamine (DIEA) $(25 \mathrm{eq})$ in $\mathrm{DMF}\left(20{ }^{\circ} \mathrm{C}\right.$ for $\left.16 \mathrm{~h}\right)$ gave a peptide resin bearing the tert-butyl esters of Ida. The final deprotection of the peptide resin using trifluoroacetic acid (TFA)-ethanedithiol (EDT) (95:5) at $20{ }^{\circ} \mathrm{C}$ for $2 \mathrm{~h}$ followed by reverse-phase HPLC purification gave Alm-[Ida]Fos. As judged by the analytical HPLC, the purity was estimated to be $>97 \%$. Yield from the starting resin, $4 \%$. MALDI-TOFMS: 7044.0 [Calcd. for $(\mathrm{M}+\mathrm{H})^{+}$: 7043.9](Figure S2). Retention time in HPLC, 25.3 min (Column: Cosmosil 5C4 AR-300 (4.6 $\times 150 \mathrm{~mm})$; Gradient: $30-90 \%$ B in A $\left(\mathrm{A}=\mathrm{H}_{2} \mathrm{O}\right.$ containing $0.1 \%$ $\mathrm{CF}_{3} \mathrm{COOH}, \mathrm{B}=\mathrm{CH}_{3} \mathrm{CN}$ containing $0.1 \% \mathrm{CF}_{3} \mathrm{COOH}$ ) over $60 \mathrm{~min}$; Flow: $1 \mathrm{~mL} / \mathrm{min}$; Detection: $215 \mathrm{~nm})($ Figure S3).

The [Ida]Fos peptide (Ac-LTDTLQAETDQLEDKKSXLXTEIANLLKEKEKLEFIL AAY-amide) was prepared as reported. ${ }^{8}$ Abbreviations for the amino acid residues are: A, Ala; D, Asp; E, Glu; F, Phe; G, Gly; I, Ile; K, Lys; L, Leu; N, Asn; P, Pro; Q, Gln; S, Ser; T, Thr; U, Aib; V, Val; Y, Tyr; X, Ida. Ac = acetyl.

$\underline{\text { CD measurements }}$ 
CD spectra were recorded on a Jasco J-600 spectrometer using a 2-mm cuvette at $20^{\circ} \mathrm{C}$. Liposomes were prepared from egg yolk phosphatidylcholine in the presence of $1 \mathrm{M} \mathrm{KCl}$ containing $10 \mathrm{mM}$ 4-(2-hydroxyethyl)-1-piperazineethanesulfonic acid (HEPES) and $1 \mu \mathrm{M}$ EDTA (pH 7.0) [final concentration of the lipid: $0.84 \mathrm{mg} / \mathrm{mL} \quad\left(\begin{array}{lll}\sim \mathrm{mM}\end{array}\right)$. The above liposomes were prepared similarly as reported. ${ }^{\mathrm{S} 3}$ Shortly, the dried film lipid (10 mg) was hydrated in $1 \mathrm{M} \quad \mathrm{KCl}$ containing $10 \mathrm{mM}$ 4-(2-hydroxyethyl)-1piperazineethanesulfonic acid (HEPES) and $1 \mu \mathrm{M}$ EDTA (pH 7.0) $(2 \mathrm{~mL})$ for $30 \mathrm{~min}$ at room temperature with gentle voltex mixing. To obtain the small vesicles, the suspension was sonicated to become clear in an ice bath for 30 min using ultrasonic disrupter and afterwards diluted to $9.5 \mathrm{~mL}$ with the same buffer.

\section{Channel activity measurements}

Planar lipid bilayers were formed on a hole with a diameter about $150 \mu \mathrm{m}$ in a thin sheet $(\sim 20$ $\mu \mathrm{m})$ of Teflon between two chambers by the mololayer folding technique as previously reported. ${ }^{\mathrm{S} 4}$ The Teflon sheet surrounding the hole was pretreated with a drop of $0.5 \%$ hexadecane in hexane to generate a hydrophobic environment for bilayer formation. Monolayers were formed by applying a few $\mu \mathrm{L}$ of Diphytanoylphosphatidylcholine dissolved in hexane $(10 \mathrm{mg} / \mathrm{mL})$ to the surfaces of aqueous solution in both the chambers below the hole. The aqueous solutions were $1 \mathrm{M} \mathrm{KCl}$ 
containing $10 \mathrm{mM}$ HEPES ( $\mathrm{pH}$ 7.0), and all the measurements were done at room temperature $\left(\sim 22^{\circ} \mathrm{C}\right)$. To avoid the effect of metals possibly contaminating the buffer and membranes, the channel current was recorded in the presence of $1 \mu \mathrm{M}$ EDTA. A bilayer is formed across the hole by successively raising the solution levels over the hole. A small quantity of the peptide in methanol (usually 1-5 $\mu \mathrm{L}$ ) was added to the electrolytes on one side of the membrane (designated as the cis side) to give a final concentration of $2.5 \mathrm{nM}$. A pair of $\mathrm{Ag}-\mathrm{AgCl}$ electrodes was used for current measurement and voltage supply. The cisand trans-side electrodes were connected to a DC voltage source and to the virtual ground of a homemade current amplifier, respectively. The output voltages of the current amplifier were recorded with a DR-F2a digital recorder (TEAC Corporation). The applied voltage was defined as the voltage of $c i s$ with respect to the compartment on the other side (trans). Channel conductance is defined as the membrane current divided by the applied voltage. The membrane current was measured under voltage clamp conditions using $1 \mathrm{kHz}$ filtering and sampling at $10 \mathrm{kHz}$.

The average channel current was calculated as follows: (i) the total ion charge going through the membrane per second $(\mathrm{pC} / \mathrm{sec}=\mathrm{pA})$ was calculated as the sum of [(the value of the respective channel current recorded at $10 \mathrm{kHz}(\mathrm{pA})) \times 0.0001(\mathrm{sec})]$, and then (ii) the averages and standard errors for (i) for a total of 25 seconds were obtained. 


\section{Additional References}

(S1) Aletras, A.; Barlos, K.; Gatos, D.; Koutsogianni, S.; Mamos, P. Int. J. Pept. Protein. Res. 1995, 45, 488-496.

(S2) Kaduk, C.; Wenschuh, H.; Beyermann, M.; Forner, K.; Carpino, L. A.; Bienert, M. Lett. Peptide Sci. 1995, 2, 285-288.

(S3) Iwata, T.; Lee, S.; Oishi, O.; Aoyagi, H.; Ohno, M.; Anzai, K.; Kirino, Y.; Sugihara, G. J Biol. Chem. 1994, 269, 4928-4933.

(S4) Okazaki, T.; Sakoh, M.; Nagaoka, Y.; Asami, K. Biophys. J. 2003, 85, 267-273. 


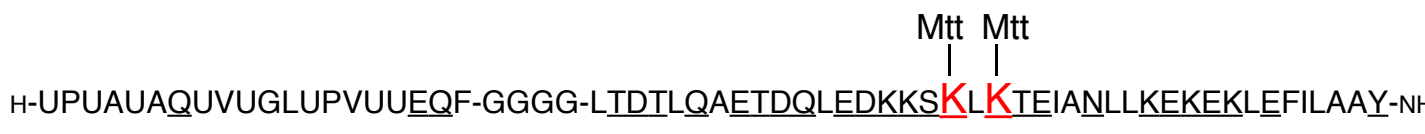

i)

$\checkmark$

Ac-UPUAUAQUUVUGLUPVUUEQQF-GGGG-LTDTLQ

ii)

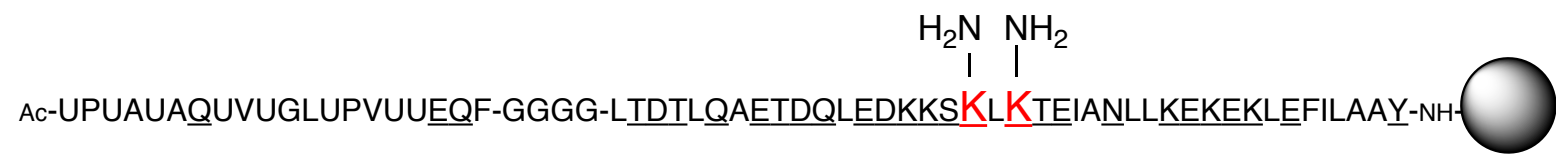

$\downarrow$ iii)

Ac-UPUAUAQQUVUGLUPVUUEQFF-GGGG-LTDTLQQAETDQLEDKKSKLLKTEIANLLKEKEKLEFFILAA $\underline{\text { YNH }}$ -

$\downarrow$ iv), v)

Ac-UPUAUAQUVUGLUPVUUEQF-GGGG-LTDTLQAETDQLEDKKSKLKTEIANLLKEKEKLEFILAAY-amide

(Ida) (Ida)

(Alm-[lda]Fos)

Supporting Information Figure S1. Preparation of Alm-[Ida]Fos using direct conversion of Lys to Ida on solid-phase resin. i) $\mathrm{Ac}_{2} \mathrm{O}$, N-methylmorpholine (NMM) / DMF, $20{ }^{\circ} \mathrm{C}, 1 \mathrm{~h}$; ii) hexafluoroisopropanol (HFIP)-DCM (1:4), $20^{\circ} \mathrm{C}, 24 \mathrm{~h}$; iii) $\mathrm{nBu}_{4} \mathrm{NI}, \mathrm{BrCH}_{2} \mathrm{COOtBu}$, DIEA / DMF, $20{ }^{\circ} \mathrm{C}, 16 \mathrm{~h}$; iv) TFA-ethanedithiol (95:5), $20{ }^{\circ} \mathrm{C}, 2 \mathrm{~h}$; v) HPLC. Ac = acetyl; Mtt = 4methyltrityl. Abbreviations for the amino acid residues are: $\mathrm{U}, \alpha$-aminoisobutyric acid (Aib); A, Ala; D, Asp; E, Glu; F, Phe; G, Gly; I, Ile; K, Lys; L, Leu; N, Asn; P, Pro; Q, Gln; S, Ser; T, Thr; $\mathrm{V}, \mathrm{Val}$; Y, Tyr; X, Ida. Side chains of the underlined amino acids are protected as: $\underline{\mathrm{D}}$, Asp $(\mathrm{OtBu})$; $\underline{\mathrm{E}}, \mathrm{Glu}(\mathrm{OtBu}) ; \underline{\mathrm{K}}, \mathrm{Lys}(\mathrm{Boc}) ; \underline{\mathrm{N}}, \operatorname{Asn}(\operatorname{Trt}) ; \underline{\mathrm{Q}}, \operatorname{Gln}(\operatorname{Trt}) ; \underline{\mathrm{S}}, \operatorname{Ser}(\mathrm{tBu}) ; \underline{\mathrm{T}}, \operatorname{Thr}(\mathrm{tBu}) ; \underline{\mathrm{Y}}, \operatorname{Tyr}(\mathrm{tBu})$. Lysine residues that should be converted to Ida are witten in red. 


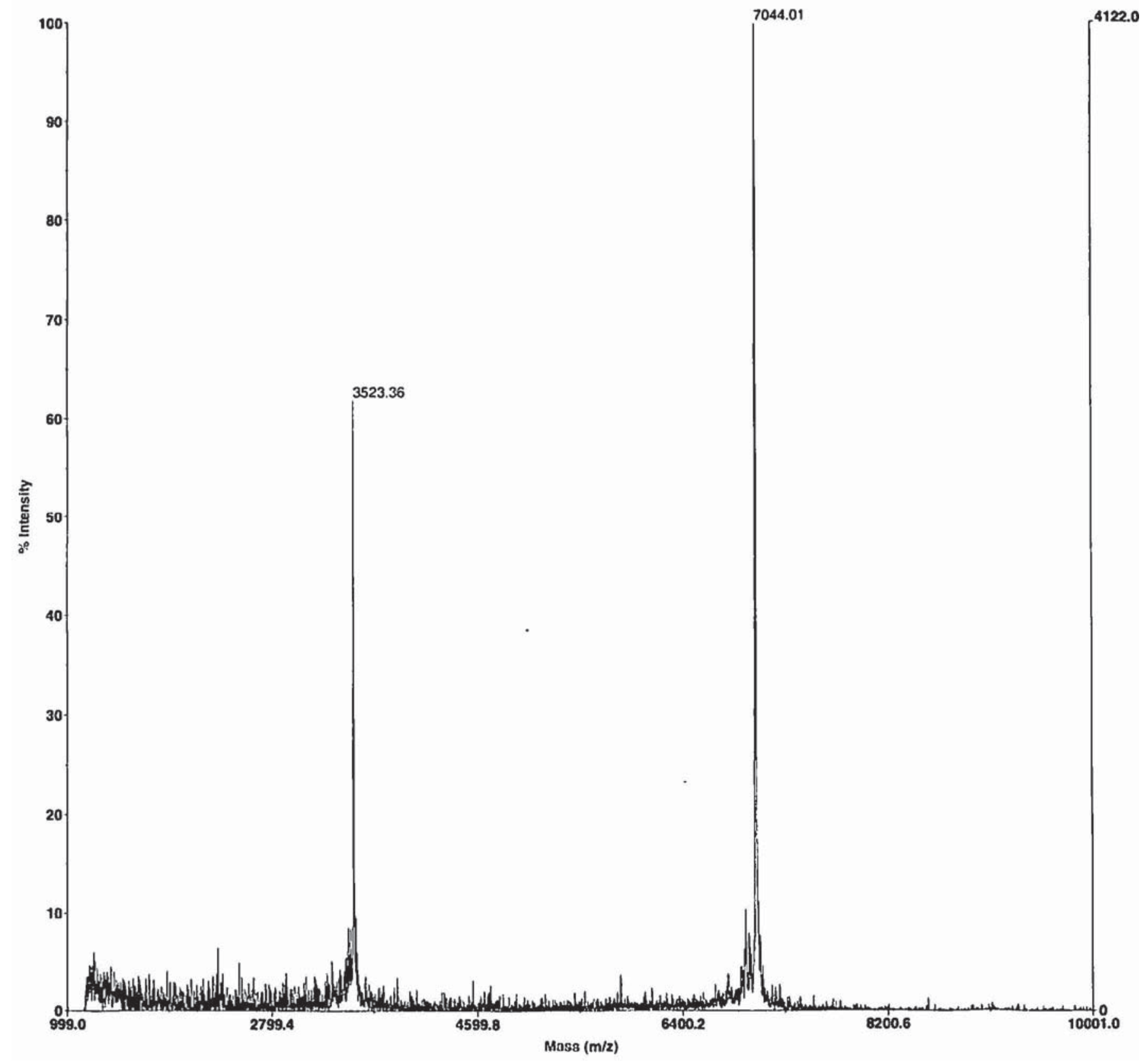

Supporting Information Figure S2. MALDI-TOFMS analysis of Alm-[Ida]Fos. 


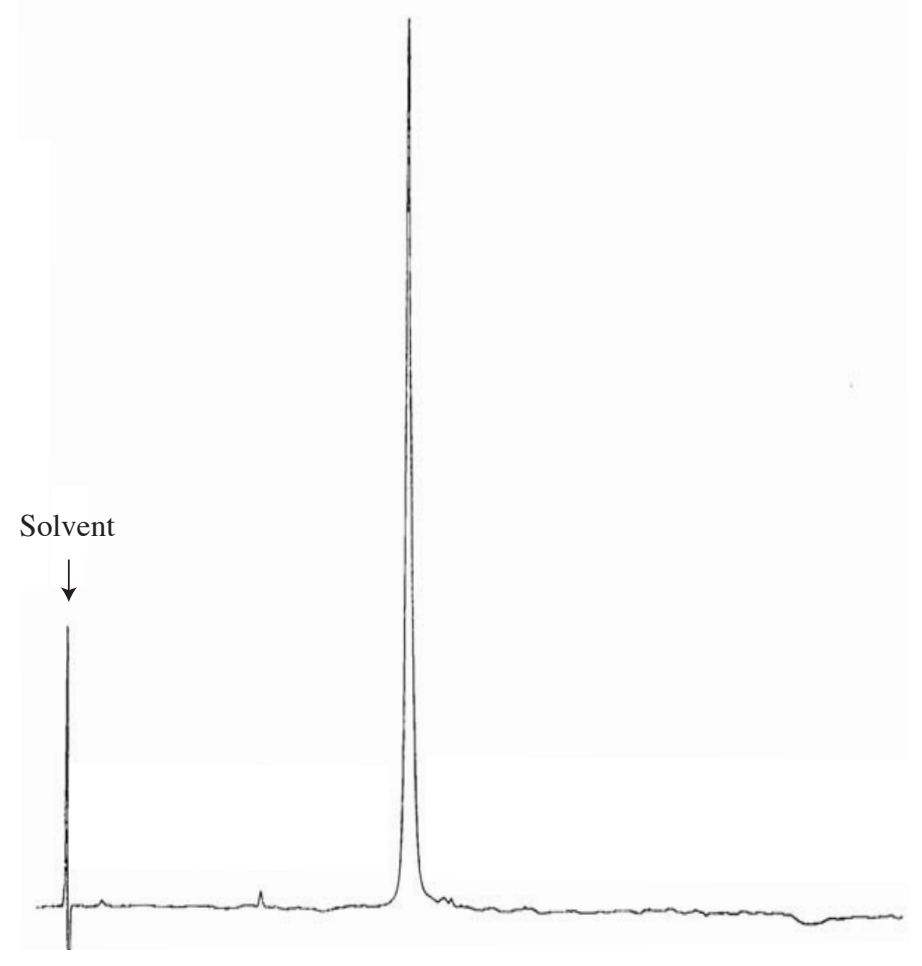

Supporting Information Figure S3. HPLC of Alm-[Ida]Fos. Column: Cosmosil 5C4 AR-300 $(4.6 \times 150 \mathrm{~mm})$; Gradient: $30-90 \% \mathrm{~B}$ in $\mathrm{A}\left(\mathrm{A}=\mathrm{H}_{2} \mathrm{O}\right.$ containing $0.1 \% \mathrm{CF}_{3} \mathrm{COOH}, \mathrm{B}=\mathrm{CH}_{3} \mathrm{CN}$ containing 0.1\% $\mathrm{CF}_{3} \mathrm{COOH}$ ) over $60 \mathrm{~min}$; Flow: $1 \mathrm{~mL} / \mathrm{min}$; Detection: $215 \mathrm{~nm}$. 
$50 \mathrm{~ms}$

50 pA

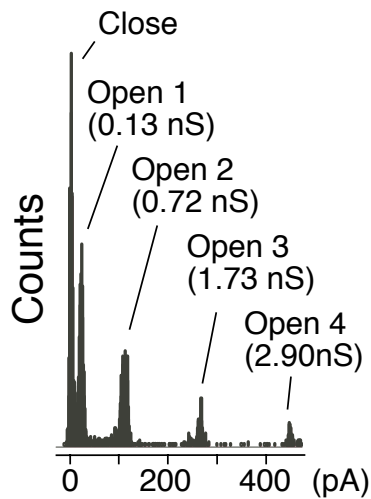

Supporting Information Figure S4. A typical channel current record from lipid bilayers containing Alm-[Ida]Fos $(2.5 \mathrm{nM})$ at $+160 \mathrm{mV}$ (left) and the current histogram (right). Electrolyte: $1 \mathrm{M} \mathrm{KCl}$ containing $10 \mathrm{mM}$ HEPES and $1 \mu \mathrm{M}$ EDTA (pH 7.0). 


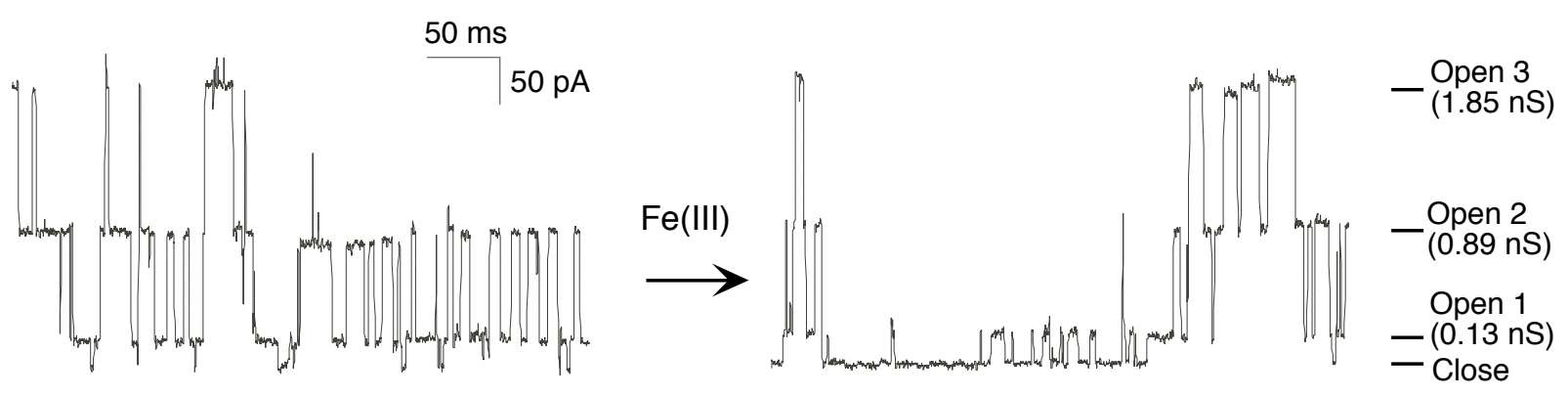

Supporting Information Figure S5. A channel current from lipid bilayers containing Alm-Fos $(2.5 \mathrm{nM})$ at $+150 \mathrm{mV}$ in the absence (left) and the presence of $2 \mu \mathrm{M} \mathrm{Fe}$ (III) (right). Electrolyte: $1 \mathrm{M} \mathrm{KCl}$ containing $10 \mathrm{mM}$ HEPES and $1 \mu \mathrm{M}$ EDTA (pH 7.0). The amino acid sequence of Alm-Fos is: Ac-UPUAUAQUVUGLUPVUUEQF-GGGGLTDTLQAETDQLEDEKSALQTEIANLLKEKEKLEFILAAY-amide (U=Aib). This peptide is identical to Alm-[cFos]LeuZ in our previous report. ${ }^{8}$ 